\title{
The Watch Movement: Searching Justice for Workers and its Families
}

\author{
Ayşe Çavdar
}

\begin{abstract}
In Turkey, four people die every day due to workplace accidents. Instead of bringing new regulations for the workers' safety, the inspection responsibilities as well as the authority of the state in the workplace have been privatized. Therefore, a group of families who lost their relatives in workplace accidents, started a movement (the Watch for Conscience and Justice) requesting public to monitor accidents and related legal regulations. Thanks to their persistent protests, workplace accidents are started to be reframed (at least in popular cases) by not only the authorities but also by the public conscience. Although mainstream media ignore these incidents unless death tolls are relatively high, these families could form a counterpublic to discuss workplace safety. Analyzing this case, I argue that the formation of counterpublic is indispensable to construct social consensus and to challenge the state's neo-liberal policies.
\end{abstract}

Keywords: Counterpublic, workplace murder, public, mainstream media, Justice and Development Party, neo-liberal policies

\section{Vicdan Nöbeti: İş Cinayeti Kurbanları ve Aileleri İçin Adalet Arayışı \\ Özet}

Türkiye'de her gün ortalama beş kişi iş yerinde, çoğunluğu inmalden kaynaklanan kazalarda hayatını kaybediyor. Üstelik, yasal düzenlemelerle iş yerinin işçi güvenliği açısından denetimi ücreti yine iş yeri sahibi tarafından ödenen özel şirketlere bırakılmış durumda bulunmaktadır. Bu bağlamda, Adalet Arayan Iş̧̧i Aileleri tarafından yaklaşık üç yıldır sürdürülen Vicdan ve Adalet Nöbeti, iş yeri, işçi güvenliği ve ilgili mevzuatın içerdiği tehlikelere kamuoyu ilgisini çekebilmek, bu meyanda süren davaların sivil toplum tarafından takip edilmesini sağlamak açısından önemli bir işlev gördü. Ana akım medyanın son zamanlarda gerçekleşen ölü sayısının yüksek olduğu vakalar dışındaki işçi ölümlerine yönelik görmezden gelme politikası delinmiş oldu. Bu makalede, Vicdan ve Adalet Nöbeti örneğinden yola çıkarak, adalet arayışındaki kesimlerin karşıkamular(muhalif kamular) oluşturmak yoluyla toplumun kendisini bir arada tutan sivil sözleşmenin yenilenmesine nasıl katkıda bulunduğu ve bu açıdan karşıkamu oluşumlarının toplumsal müzakere açısından taşıdığı hayati önem ele alınmaktadır.

Anahtar Sözcükler: Kamuoyu, muhalif kamuoyu, işyeri cinayetleri, anaakım medya, Adalet ve Kalkınma Partisi, neo-liberal politikalar 


\section{The Watch Movement: Searching Justice for Workers and its Families}

In Turkey, four people die every day due to accidents in the workplace. ${ }^{1}$ Since the AKP (Justice and Development Party) government's ambitious politics on economic development rely heavily on the riskiest sectors, such as construction, mining, energy production via dam projects, and since safety measures make the production and the cost of labor more expensive, the government does not apply all legal measures regarding worker's safety. Furthermore, a new law ${ }^{2}$ issued by the AKP government has replaced the term "workers' safety" with "workplace safety". The change in the law means a serious reduction of employers' responsibility directly affecting workers' safety. Furthermore, both the inspection responsibility and the authority of the state in the workplace are privatized and transferred to the companies and experts hired by employers. In fact, although the previous regulations made both the state and employers more liable for workplace accidents, the courts never put this principle into practice. First of all, the state has never allowed any court to try a public officer (neither municipal, nor governmental) for a workplace accident. Secondly, and maybe more importantly, workplace accidents have generally been seen as compensation cases by the courts and have rarely ended with punitive decisions for the liable parties. From this perspective, I argue that the new law (just) institutionalized and legalized the practical situation in terms of the non-responsibility and (punitive) immunity of both the state and the employers, concerning the legal consequences of the violation of the measures of workers' safety. Although there are a series of negative changes in the establishment of workers' safety, 
some cases have resulted in unprecedented court decisions since these cases monitored by the families, activists, and the media. Furthermore, the decisions of court "breach" the irresponsibility and the immunity of the state. However, neither the developmentalist economy policies of the government nor the tendency of courts to protect "the state" in the name of "the public" (as state) means the public (as people) stop discussing issues related to workplace accidents.

In this article, based on the case of "the Watch for Conscience and Justice" (Vicdan ve Adalet Nöbeti, the Watch from now on), I will demonstrate the ways in which a counterpublic formation can help to develop a claim for justice on behalf of the groups which unable to represent or explain their opinions in mainstream media. In other words, I will explain how and in which ways a counterpublic can impact the formation and discourse of (mainstream) public via its performative potentiality and insistence on its cause. I will focus on these questions through narrating the story of the Watch by utilizing the term counterpublic. In my case, the Watch is organized by the Worker Families Seeking Justice (Adalet Arayan İşçi Aileleri, the Families from now on) to receive public support for their cause. These families' cause is shaped to seek justice for their loved ones who died in workplace accidents. Forming a "counterpublic" concerning workers' safety, these families transform their procedural struggle for justice into a public debate on the "nature" and regulation of the workplace. The formation of this "counterpublic" started with an attempt to redefine and rename a series of concepts, like "accident", 
"safety", "workplace". Afterwards, through their persistent and frequent public protests, the Families were able to involve (real) "strangers" in their struggle. Moreover, calling the public to monitor court proceedings related to workplace accidents, the Families help society to revitalize its basic principles, such as justice, economic wealth, and the responsibility of the state, both in popular culture and in the procedural domains related to these basic principles of any society.

In order to analyze the Watch Movement first I will focus on the neoliberalization of labor policies in the AKP period.

\section{What is "neo" in AKP's labor policy?}

The AKP inherited the economy politics of previous centre right parties that ruled Turkey between 1980s and 2002 based on the liberalization in the market mechanism. Due to repetitive political crises, such liberal economic policies were shaped in collaboration with international financial institutions, such as International Monetary Fund (IMF) and World Bank (WB) to create an efficient economy that is able to pay the debt of a country (Onis, 2012). As part of global neoliberalization of economy, Turkey's internationally constructed liberal economic policy has been based on privatization, open market regulations (or maybe relations) and deregulation of all the sectors in the economy (Buğra and Savaşkan, 2014:113). In terms of labor policy, this process meant de-unionization of the working class (Çelik, 2012) and flexibilization of the labor market (Dereli, 2014) as happened all over the world in the last decades. The aim of deregulations in labor relations is to decrease the cost of production for investors. Therefore, workers' safety is regarded as one of the biggest and easily reducible expense item.

One of the main tools of international actors of Turkish economy was the formation of autonomous regulatory agencies in the main sectors of economy, such as BDDK (Banking Regulation and Supervision Agency) in banking sector, EPDK (Energy Market Regulatory Authority) in energy, TK (The Council of Tobacco) in tobacco and the 
SK (The Council of Sugar) in sugar production (İslamoğlu, 2002) as well as the fortressed autonomy of Central Bank and Stock Exchange Market. The latter two councils (TK and SK), together with a series of regulations made for integration with the European Union changed the whole structure of the agriculture sector that aimed the integration within global markets. Such regulations brought further commercialization of agriculture and less support from the state for the sector. This policy caused a tangible de-growth in the agriculture sector and unemployment for those people who are unqualified for the industrial or service sector. Later on, especially after the mine accident in Soma the precarization of those unemployed villagers became more visible. ${ }^{3}$

Meanwhile the increasing autonomy of those regulatory agencies was an impediment for the AKP government to follow an independent economic policy. Under the strict international monitoring on economic sectors, unlike the previous governments utilized public investments to create their particular political economies, the AKP, in its first years, was unable to use public sector as a distribution mechanism. (Buğra, 1994; 95-156). Under such circumstances, the AKP government chose to create or boost some other sectors not under strict supervision of those internationally constructed autonomous agencies. Therefore some economic sectors, such as construction 4 , mining5; energy production ${ }^{6}$, which are the riskiest ones in terms of workers' safety and environment have been boosted since the second governmental term of the AKP, began in 2007.

\section{Making deceased workers visible}

The coup d'etat of 1980 made a fatal impact on Turkish unionist movement. First, all the trade unions were closed until 1983. Afterwards, some of the unions were allowed to function within a new legal structure, which limited the political rights of the organized working class. The new legal framework limiting the rights of strike and organization reduced the power and effect of trade unions in the political scene. Together with the downsizing of public sector by 
increasing privatization, employing most of the organized working class, de-unionization process and eroded political power of labor unions is left working class alone against government and employers in the neoliberalization process of economy. Furthermore, the wide use of sub-contractor system has a huge negative effect in the empowerment of the working class, especially in the riskiest sectors such as mining, shipbuilding, and construction. Under such circumstances, the issues related to the workers' safety have become more and more striking and seen as one of the main subjects by especially social movements that oppose to the government's afore-mentioned economic policies.

During the rule of AKP, one of the most popular public campaign related to the workers' safety was related to the death of workers in Tuzla Shipyard. Beginning in 2008, mainstream media widely covered the death of workers in Tuzla Shipyard thanks to the effort of not only trade unions (in this case Limter-İş), but also chambers of related engineering professions such as chemical engineers, metallurgy engineers and a group of academicians, and journalists. In 2008, Mazlum-Der, a human rights organization found by a group of religious intellectuals prepared a report ${ }^{7}$ related to the workers' deaths in Tuzla Shipyard. By the initiation of Limter-İ̧, a commission was formed to make an independent research on workplace accidents in Tuzla, named the Monitoring and Research Committee for Tuzla Shipyard Area ${ }^{8}$. this committee is formed by engineers and lawyers, as well as social scientists and journalists, a group of people who had a pioneering role in the formation of a new understanding and conceptualization of the issue of workers' safety (Akdemir and Odman, 2008; 50)

During this period, another popular case related to the workers' safety was the increasing death cases of the workers employed in sandblasting of denim. Similar to the case in Tuzla Shipyard, parallel to the frequent appearance of the news reports in mainstream media on the workers lost their lives because of silicosis disease -caused by the sandblasting process in denim textile- a huge public campaign started. Collaborating with human rights organizations, the chambers 
of engineers, academicians, and journalists, denim workers formed a committee named Solidarity with Sandblasting Workers9. In 2010, sandblasting was prohibited by a decree of the Ministry of Health and silicosis accepted as an occupational disease. Afterwards, human rights organizations, academicians, journalists, and partly labor unions collaborated on many cases related workers' safety as well as work security, such as the unionization of construction workers (Initiative for the Union of Construction Workers ${ }^{10}$ ), domestic workers (IMECE Domestic Workers' Union), the formation of Assembly for Workers' Health and Safety ${ }^{11}$, the formation of Ozgur Kazova Cooperative ${ }^{12}$.

\section{A Watch for Justice}

Istiklal is one of the busiest pedestrian streets of Istanbul. Although it has been transformed into an open-air shopping mall in the last two decades, it is still a very important political space for many groups that want to have a say about the world politics, events as well as their own surroundings. During an ordinary weekend, a person is very likely to come across at least two or three different protests on Istiklal, of course, the political manifestation of any given group is surrounded by the advertisements of shops on both sides of the street. Among all these messages, the message of the political protest is generally lost, if the group is not large enough or in many ways entertaining. As a way to avoid the possible outcome (e.g. police violence) of political protests, if there is one around, the "ordinary" public on Istiklal generally turns a deaf ear and avoids getting involved in the continuing political action. If the police attack to protesters, shops turn into casual shelters for street dwellers. On the other hand, it is obvious that by being there, this "ordinary" and "coincidental" public is the first and privileged target of all the protests, as well as the marketing activities performed in the street, somehow not only competing against each other, but also completing each other.

One of the most visible spots on Istiklal Street is Galatasaray Square, a well-known and small space that has hosted the Saturday 
Mothers since May 1995. Meeting and sitting silently for half an hour in this square, tens of Kurdish women, the majority of whose children were lost under surveillance by the Turkish state ${ }^{13}$ during the 1990s, perform civic disobedience every Saturday. Since May 2012, there has been another group of people that meets in the same spot on the first Sunday of every month to tell their stories to the "ordinary" and "occasional" public of Istiklal Street. This group of people is composed of families seeking justice for their relatives who died due to accidents in the workplace. The name of this protest is "the Watch for Conscience and Justice" (Vicdan ve Adalet Nöbeti). Similar to the Saturday Mothers, these families call on the public to monitor court cases and procedural developments related to workplace accidents together. The protest starts with a press declaration generally read by a young representative of the families. After announcing the monthly death toll of workplace accidents, the representative reiterates the demands of the families addressing the government and involved courts who are not represented / present in the square during the course of the protest. The press declaration ends with a call addressing an undefined group of people: "We ask that nobody else joins us here to seek justice for their loved ones. We wish nobody is murdered in their workplace while trying to earn a living. We are just here to claim justice, not only for our children, brothers, sisters, wives and husbands, but also for those under risk. Listen to our stories and keep the courts under close surveillance in order to avoid further deaths." After this press declaration, a journalist comes to interview representatives of the families in order to inform the public about the related court proceedings. At this point, journalism and interview activity are utilized to tell the public the stories of the dead workers and inform people of the court proceedings.

\section{What is Public in Workplace Murders?}

The complexity and power of the term, public, derive from its indefinable content. Its vagueness makes it inevitable in all struggles and negotiations, especially in the context of modern democracies. Thus, the term public generally functions not as the space or base of 
any sort of struggle or negotiation, but as an imagined (Anderson, 2006; 6) reference, especially in the legitimization of any political, economic or social claim. At the risk of oversimplifying, it can be said that any struggle/negotiation in any democratic context is, in fact, a struggle for the ability to re/form the imagined public.

In the most common idealistic theorization of democracy, the public sphere is mentioned as the imagined space of rational negotiation/struggle among all the equal parties forming any democratic society (Habermas, 1991; 27). According to this definition of the public sphere, the public is formed by imagined and unidentifiable actors, who seek to realize their reasonable interests, within the formation of imagined public sphere. Being different from the formation of any community, the public is formed by people or individuals who are connected to each other through "common concerns" (Habermas, 1991; 37) through countless and generally indirect means of communication. In light of such a definition and considering the unequal distribution of the means of communication, it is difficult to claim that the practical public sphere is democratic and that the public has equalitarian characteristics. In practice, the public sphere appears as an imagined space in which all parties of any society are represented in proportion to their power, and the power, in general, cannot be identified by either the numbers or "rightfulness" of people forming an interest group within a given society. Thus, in practice, the public sphere is an imagined space full of the signs of radical inequalities created within any society. On the other hand, this pessimistic scenario is broken frequently by the invention of new means and strategies created by people seeking power to be represented in not only the "imagined" public sphere, but also in practical negotiations on the future of any given society. Hence, public negotiation / struggle and the public sphere also have performative characteristics and content. In other words, an interest group can also be represented in the formation of the public in proportion to their performative potentiality and ability (Butler and Athanasiou, 2013; 15).

In my case, although the subject, workplace accidents, is one of the most common problems in the current conditions of economic 
production in Turkey, neither the reasons and consequences nor preventative measures, were dealt with in the public discussion up until a few years ago. The struggle to make work place accidents visible in the public domain started with a series of renaming practices. First, the families who had lost their relatives in workplace accidents named themselves as "Worker Families Seeking Justice". Second, these families also renamed "workplace accidents" as "workplace murders," to indicate the preventable characteristic of these incidents and to remove the quality of violated responsibility of the related parties in the workplace. In doing so, the families redefine the positions of the responsible parties and break the normalization habit of these "accidents" in the public discourse. Moreover, naming their protest "the Watch for Consciousness and Justice" those families generalized their claims in all segments of society. Instead of seeing their struggle as unique, those families re-contextualized it as a struggle for the sake of the whole society. The renaming strategy created by the families and volunteers of Bir Umut Association created a space in the stratified and fragmented (Fraser, 1990; 66) public sphere to re-conceptualize the main issues related to the establishment and process of economic production. In this manner, they started forming a counterpublic addressing a wider and indefinite group of strangers through a wider definition of the problem within which they continued to struggle.

I argue that this new public (if we refer to it as such) is too large in quantity to become a counter public in terms of its addressees. First of all, dealing with workers' safety in the workplace, such public sphere addresses all parties of any economic production. Secondly, since it claims transparency in court processes, the counterpublic also addresses all parties associated with the current justice system. Finally, claiming punishment not only for employers, but also for those representatives of public institutions holding the authority of inspection in the workplace, the counterpublic addresses the entire public sector and governmental institutions. Considering the normalization of workplace accidents $^{14}$ in these domains, it is not particularly easy to create a discursive space for these issues in the stratified public. At this point, the performative ability of families and supporting groups appears as 
an important asset. Not only renaming the issue, but also problematizing the public negotiation processes related to the renamed issue, the Families redefines workplace accidents as a phenomenon directly connected to the current social justice landscape in Turkey. Therefore the Families try to open a domain, in which all segments and groups of society should question their own contribution regarding the occurrences of workplace "murder". Thus, the call of justice made by the families is in itself a call to rethink the quality of existing public.

\section{From Workplace Accidents to Workplace Murders}

The protest of the Families, or in other term, the monitoring movement started after an explosion took place in Davutpasa, Istanbul, on 31 February 2008. The explosion, which killed 21 and injured 116 people, took place in an informal firework workshop. The public prosecutor prepared a report referring the responsibilities to not only the owners of the workshop, but also the public offices that had the authority of inspection. According to the technical report, the owners of the workshop were guilty, but the public authorities including Istanbul Metropolitan Municipality, Ministry of Labour and Social Security, Zeytinburnu Municipality and BEDAS (the electricity distribution company) were also negligent. The court case could not start until November 2009, and because of this reason, families initiated the Watch Movement. Then, the court case opened, but the indictment did not include the public authorities indirectly involved in the case. Thus, the families decided to go on with the Watch until the public authorities were brought to justice. After 39 weeks, the only progress they had made was the inclusion of Murat Aydin, Zeytinburnu Mayor together with 5 municipal officers, and Atakan Tanis, the Istanbul Regional Director of the Ministry of Labour and Social Security. All these public officers were included in the indictment with claims of reckless homicide and malpractice. The first period of the Watch ended with this progress.

From the beginning, the families that started the Watch movement, by the legal and conventional assistance of Bir Umut Association, 
claimed that most workplace accidents were in fact murders, because they were all the consequences of a series of responsibility negligence by firms and government offices. According to them, although the potential accidents are seen and known by all parties involved in the workplace, these accidents should be accepted as murders, and all the parties should be judged and punished for their responsibilities in these crimes. The families of the Watch replaced the term "workplace accidents" with the term "workplace murders" through the frequent and persistent usage of the term. During the years, at least in the nonmainstream media, this term helped to establish a new public framework for these incidents.

Although the media coverage was not sufficiently widespread to create a public agenda around workplace murders, the Davutpasa families were followed by other families who had lost their relatives in workplace murders. With the participation of new families, the legal struggle against workplace murders spread across different sectors including mining, television, energy, construction, and housework. The Watch, in this first period, had two different messages to two different audience groups which directly related to each other. The addressee of the first message was the courts. The families said that they would persist with their legal struggle and would not be satisfied with the usual proceedings applied in similar cases. The second message, on the other hand, went to public opinion, in their weekly Watch in Taksim Square, the families called upon public to rethink workplace accidents and monitor related courts to establish a secure legal framework for better working conditions.

\section{Telling the Story-Forming the public}

Two years after the first Watch Movement ended, on 20 May 2012, the second Watch Movement started. This time the subject of the Watch was not only the Davutpasa case, but all cases of workplace murders, legally assisted by the pro bono lawyers of Bir Umut Association. The aim of the Watch, this time, was not only to monitor a definite case, but all similar cases and general procedures related to worker safety in the 
workplace. The Watch Movement was not only demanding justice in courts, but also better regulations addressing all the responsible parties such as municipalities and the Ministry of Labor, as well as necessary measures in all the sectors of economy.

In the first Watch, the families came together in Taksim Square. They put up their banners and waited for the audience for a while. Later, the press declaration was read and slogans were shouted. Meanwhile, a Circassian group was waiting to make their own protest. At the end of the Watch, a couple of protesters from the Circassian group approached the Families and asked the reason of the protest. Obviously, the message did not reach the Circassian group, although they were just 5 meters behind the Watch.

Similar to the first one, the second Watch was also intended as a weekly action. However, considering the lack of interest, the families and volunteers of Bir Umut Association decided to find another way. The slogans were replaced by the stories of the dead workers. Considering the consequences of politically overloaded Taksim Square, the Families moved the Watch to Galatasaray Square. To create a context to tell the stories, the Watch invited a journalist to interview with the families. The voice of the interview would be broadcasted through a megaphone to attract the attention of people walking down Istiklal Street. Meanwhile, volunteers would talk to people in the street asking about the conditions in their workplaces. By these techniques, the Watch would become more open to the participation of the public, in this case the passersby. Moreover, the whole event would be recorded by cameras to broadcast at a later occasion through websites and social media.

For the first new Watch, journalist Perihan Ozcan was invited. ${ }^{15}$ On 27 May 2012, the Watch was performed within its original format. The interview made by Ms. Ozcan was the most efficacious part in terms of reaching the audience. Tens of people listened to the families interviewed by the journalist. For an hour, the square turned into a TV studio broadcasting live. 
However, the second part that relied on street interviews with the passersby did not work. The first question of the interview "are you a worker?" was usually answered, "No, I am not." People did not consider themselves as workers, although they worked for companies as accountants, secretaries, marketing representatives etc. It also created distraction from the family interviews, thus this part would not be repeated in the following Watches.

Virilio, starts his inspiring and thrilling Speed and Politics, with a paragraph suggesting the revolution would not happen in factories, but in streets, because the energy of the means of production can only be replaced in streets, with the coincidental but conscious meeting of all passersby (2006:29). Warner also highlights the importance of strangers in the formation of a (counter) public. Accordingly, without strangers the subject of speech/text etc, is contained in the private sphere of any given group formed by acquaintances (Warner, 2002; 417). For Warner, the stranger is the existential base of the modern social imaginary, because only with strangers this imaginary can exist.

In the case of the Watch, a group of people who have experienced the same pain in different contexts gather to seek justice for their relatives. However, such a common concern is not sufficient to create a public around the workplace murder issue. Only, when the families attract absolute strangers, people who did not experience pain emanated from murders (yet), will the families begin to form a public around their issue. In order to form such a public, the Families invented a new language to define their cause and a performative form on the street to make their stories heard. By this way, the Watch produced a way (Warner, 2002; 422) to rethink, re-conceptualize, re-articulate and re-contextualize workplace accidents. The domain the Watch created together could be named the subaltern counterpublic (Fraser, 1997; 82) with its dual character. First, the Families redefined themselves as the "Worker Families Seeking Justice" and through their activities these families formed a wider public around their cause.

I do not believe it is necessary to argue whether or not the Watch is a movement which is consciously aiming to create a counterpublic 
about workplace murders. My aim here is to draw attention to how vital these movements are in terms of the survival of societies. Instead of searching for revenge or giving up on their rights, the Watch struggles not only in the courts, but also on the streets in order to remind society of its basic promises about all members of society. From this point of view, any movement seeking justice (I am not familiar with any social movement that does not mention or demand justice) revitalizes the basic foundations of society. In this sense, the identification of a wider public (the world of strangers) with an articulated problem (workplace accident) becomes possible through a reflexive bondage created within the families' language of the public performance. In order to create this reflexive bondage and evoke basic principles of society, the Families persistently repeated below sentences in their press declarations throughout the course of the Watch:

All the responsible parties, without any exception, should face court process. We will continue our protest until this demand is realized. We, as the Worker Families Seeking Justice, meet every month in Galatasaray Square for the Watch for Consciousness and Justice. Because;

- Until all the judges, prosecutors, court experts see workplace murders as a crime against public order, until they decide to be just, conscious and brave in this issue,

- Until the government takes the necessary measures to force all the responsible parties related to any workplace murders to be judged thoroughly,

- Until all employers are effectively forced to take measures for worker's safety,

- Until all labor unions and political parties who pretend to be supportive to workers carry out their original duties,

Workplace murders will continue. We will struggle to change what has happened. We, the families, thank all the people and institutions that support us in our struggle for justice. Let your eyes, ears, bodies and consciousness stay with us. 


\section{Effectiveness of the Movement}

Thanks to the Movement, the media coverage on workplace murders increased significantly during the last three years. The families regularly addressed the issue in various contexts, not only through the Watch, but also their other activities, such as visiting other families with new workplace murder cases as well as visiting Istanbul Technical University to urge law professors employed by the courts as consultants to write their reports on work place accidents in the light of their conscious not bureaucratic sensitivities. ${ }^{16}$ I observed that the novelty of the format and the participation of journalists in the Watch, to make journalists and the public remember the main principles of journalism as a job, attracted a lot of attention. Although the crowd in Taksim square surrounding the families during the Watch was not that large, the meaning assigned by this crowd was more noticeable. Furthermore, the Watch was carried out on other media platforms by the assistance of volunteers, photojournalists, and other people coinciding with the Watch.

In time, the effect of the Watch was almost visible in court rooms. One of the first instances was again in the Davutpasa case. Zeytinburnu Mayor Murat Aydin was invited to the court to give his testimony as one of the felonies. However, the Mayor sent a report stating that he was unable to appear at the courtroom due to the health reason. Enis Tayman of Radikal, one of the journalists that participated in the Watch before, tracked the Mayor down to figure out if the health report was indeed true. Checking the Mayor's social media accounts, Mr. Tayman found out that the Mayor visited Dolmabahce Palace during the hours of the court case. Moreover, the Mayor shared pictures on Instagram, taking his "off day" as an opportunity to spend time in the city. There were also images showing the mayor participating in a special party organized by the Giresun community in Istanbul just hours earlier before the court. The news report appeared in Radikal under the heading of "Mayor Expected in Court Appeared on Instagram" (Mahkemede Aranırken Instagram'da Çıktı") on 15 September 2012. Considering this behavior as disrespect to the court, the judge issued 
an arrest of the mayor in case he did not appear in the court room for a similar reason. By this way, finally, Mr. Aydin was successfully brought to the court, although he thought this was just a bureaucratic detail.

Seeing how news reports could have an effect on court decisions, families and Bir Umut volunteers decided to continue the Watch. More importantly, seeing the stories related to the Watch, other families called Bir Umut Association and wanted help to take their workplace murder cases to court.

The Davutpasa case ended on 13 July 2014 with a decision sentencing two high rank officers of Zeytinburnu Municipality (Rustem Tekin and Feruz Kutsal) to 7.5 years jail for reckless homicide. Two other officers (Sevket Yildirim and Servet Kirna) were sentenced to 4 years 2 months for malpractice. The Director of Urban Planning of the municipality, Hatice Kucukakyuz was also sentenced to 2.5 years jail. The owners of the firework workshop, Resul and Remzi Kocyigit were sentenced to 5 years. However, the Mayor of Zeytinburnu, Murat Aydin was acquitted and all jail sentences were liquidated. Even though this is the first example of a case that identifies public institutions with a wider range of responsibility and ends in a decision including punitive measures, the families decided to continue their legal struggle in the higher courts for further punishment of responsible parties and better regulations on worker safety.

\section{Conclusion}

The importance of the Watch as a counterpublic formation relies on its power to impact the discourse and the content of the public debate regarding the workplace accidents phenomenon. Although general public and responsible parties tend to frame workplace accidents as "natural" part of economic development (for all), the Families persistently claimed that workplace incidents are not simple accidents but the consequence of a conscious and obvious economy policies, prioritizing a specific group (investors) over another one (workers). To be able to demonstrate the link between the "nature" of 
workplace accidents the families invited the whole society to examine its understanding of justice. By this way, the families did not only impact the procedural realization of justice in courts, but also assisted the whole society to understand the link between procedural and distributive justice mechanisms.

In this article, I explained how the formation of a counterpublic is vital not only to fortify the democratic institutions of any society, but also to keep any society alive. A counterpublic (formation), organized around re(de)fines and regenerates the values that keeps a society together. Justice is one of those basic principles and functions of a society, which provides an original bondage between an individual or group and the whole social existence. Seeking and struggling for justice before the whole society, a person or a group, in fact, provides an opportunity to the given society, to renew and re-evaluate its common principles as it happened in Turkey. Thus not only the contents of court decisions on the incident subject to the formation of such a counter public, but also the quality of public/popular support in her / his struggle for justice determines the persons' satisfaction with the court decision. Furthermore, this means that such (expectation) satisfaction keeps individuals together. Thus, the visibility of the struggle for justice and the support of strangers keep the "social contract" alive and reliable. 
Çavdar • The Watch Movement: Searching Justice for Workers and its Families • 127

\section{References}

Anderson, Benedict (2006), Imagined Communities, 2nd edition, Verso, London.

Buğra, Ayşe and Savaşkan, Osman (2014), New Capitalism In Turkey: The Relationship between Politics, Religion and Business, Boğaziçi University, Turkey.

Butler, Judith and Athanasiou, Athena (2013), Dispossession: The Performative in the Political (Conversations with Athena Athanasiou).

Çelik, Aziz. (2012), “Trade Unions and Deunionization during Ten Years of AKP Rule*, (Heinrich Böll Stiftung), 44-8, http: / / www.tr.boell.org/ downloads/AZIZ_CELIK_eng.pdf)

Dereli, Tekin (2014). “Flexicurity and Turkey's New Labor Act: Problems and Prospects", Labor and Employment Relations in a Globalized World Contributions to Economics 2014, pp 135-158.

Habermas, Jurgen (1991), The Structural Transformation of Public Sphere: An Inquiry into a Category of Bourgeois Society, MIT Press, Cambridge, Massachusetts.

Fraser, Nancy (1990), "Rethinking the Public Sphere: A Contribution to the Critique of Actually Existing Democracy", in Social Text, No. 25/26, pp.56-80.

Fraser, Nancy (1997), Justice Interrupts: Critical Reflections on the "Postsocialist" Condition, Routledge, New York.

İslamoğlu, Huricihan (2002), “IMF Kaynaklı Kurumsal Reformlar ve Tütün Yasası”, Birikim Dergisi, Sayı: 158, Haziran 2002.

Öniş, Ziya, “The Triumph of Conservative Globalism: The Political Economy of the AKP Era" (February 10, 2012). Available at SSRN: http:/ / ssrn. com / abstract=2003026 or http: / / dx.doi.org/10.2139/ssrn.2003026

Warner, Michael (2002), "Publics and Counterpublics" (abbreviated version), Quarterly Journal of Speech, Vol.88, No.4, pp.413-425.

Virilio, Paul (2006), Speed and Politics, translated by Marc Polizzotti, Semiotext(e), Los Angeles. 


\section{Endnotes}

1 Isa Yazar, "İşs kazalarında her gün 4 isçi ölüyor", 9 April 2014, Zaman Gazetesi, http://www.zaman.com.tr/ ekonomi_is-kazalarinda-her-gun-4-iscioluyor_2209880.html

2 "Occupational Health and Safety Law" (İş Sağlı̆̆ı ve Güvenliği Kanunu), number: 6331, 30 June 2012

3 According to a report prepared by a group of academicians from Boğaziçi University (Boğaziçi University Research Group for Soma), most of the workers died in the mine accident in May 2014, were those villages lost their income because of the regulations/restrictions of tobacco production. “Boğaziçi nin Soma Raporu: Büyüme fetişizmi facia getirdi, sendika mafya taktiği uyguluyor", 3 February 2015, t24.com http:/ / t24.com.tr/haber/ bogazicinin-soma-raporu-buyume-fetisizmi-facia-getirdisendika-mafya-taktigi-uyguluyor,285960

4 Including mega-projects in metropolitan cities and huge urban transformation projects.

5 Especially coal and gold.

6 Through thermal power stations and dam projects aiming not only energy production but also privatization of water resources.

7 “Tuzla Tersaneler Bölgesi Gözlem ve Değerlendirme Raporu”, http://istanbul. mazlumder.org/main/yayinlar/yurt-ici-raporlar/3/tuzla-tersaneler-bolgesigozlem-ve-degerlendi / 484

8 Tuzla Tersaneler Bölgesi İzleme ve İnceleme Komisyonu - TTBİK

9 Kot Kumlama İşçileri Dayanışma Komitesi, http://kotiscileri.org/category/ english/

10 The foundation procedure of the Union of Construction Workers completed in August 2014.

11 İşçi Sağlığı ve Güvenliği Meclisi, an initiative formed by academicians, journalists, and activists to publicize all the issues related to the workers' safety http:/ /www. guvenlicalisma.org/

12 A cooperative found by the textile workers, who were fired by Kazova company, http:/ / ozgurkazova.org/tr/. In this case, not only advocacy for fired workers but also an alternative production model is organized in collaboration with workers, artists, journalists, intellectuals and activists from a wide range of different backgrounds. 
Çavdar • The Watch Movement: Searching Justice for Workers and its Families 129

13 Özgür Sevgi Göral, Ayhan Işık, Özlem Kaya, "The Unspoken Truth: Enforced Disappearances", http://www.hakikatadalethafiza.org/images/UserFiles/ Documents/Editor/Yayınlar/Konusulmayan-Gercek_ENG.pdf, Truth, Justice, Memory Center, 2014

14 One of the most famous quotes of current president Tayyip Erdoğan explains workplace accidents with the nature of work itself: "Work place accidents are ordinary. There is something in literature called work place accident. These accidents happen because of the nature of mining. However, the high death toll deeply injured us." 14 May 2014, after 302 people were killed in a coal mine in Soma.

15 The list of journalists participated in the Watch since 2012: Pinar Ogunc, Enis Tayman, Ismail Saymaz, Gulsah Karadag, Isin Elicin, Balcicek Ilter, Melek Ulagay, Isminaz Ergun, Ertugrul Mavioglu, Ayse Cavdar, Elif Ince, Mustafa Alp Dagistanli, Mujgan Halis, Pelin Cengiz, Ahmet Sik, Zeynep Mirac, Kemal Ozmen, Mehmet Efe, Ayca Orer, Burak Oz, Elif Bereketli, Mirgun Cabas, Sevgim Denizalti, Ozcan Yuksek, Hayati Bakis, Banu Guven, Mehves Evin, Mustafa Kemal Erdemol, Fatih Pinar, Merve Erol, Ali Topuz, Burcu Karakas.

16 "Ailelerden bilirkişilere 'adil olun' çağrısı," (A call from families to court consultants to be just) 21 October 2014, Birgun, http: / / www.birgun.net/ news/view / ailelerdenbilirkisilere-adil-olun-cagrisi / 7567 